\title{
Fast Food Nation
}

\author{
Eric Schlosser \\ New York, NY: Houghton Mifflin Co., 2001. 356 pages.
}

Combining in-depth historical and socio-political analyses of the American food industry with an easy-flowing language style, Fast Food Nation is nearly impossible to put down. Mind-boggling in scope, yet as intimate as one's own kitchen, this book allows the reader to grasp the true horror of the global food situation. Schlosser provokes both laughter and tears, ultimately inspiring the reader to engage in the "higher jihad" of controlling one's appetite with the understanding of how personal consumer choices have political consequences.

Section One, "The American Way," takes us through four chapters. The first, entitled "The Founding Fathers," talks about how the mass production of the automobile transformed post-WWII American society and its land- 
scape, and introduces us to the hard-working businessmen who gave fast food a permanent place in the car culture, replacing the lovely countryside with a nearly identical, ugly sprawl of fast food restaurants, subdivisions, and strip malls in every town.

Chapter 2, "Your Trusted Friends," explains the appeal of the fast food industry to children and adults longing for their past childhood through the use of toys and mascots such as Ronald McDonald and Taco Bell's talking dog. Gearing advertisements to the psychology of children has become a big business. All the major toy crazes such as Beanie Babies and Pokemon have been promoted by fast food chains. Cross-promotions extend to cartoons, movies, amusement parks, and now schools. Due to funding shortages, many schools have started promoting brand names of fast food and soda companies, whose ads now cover school hallways, buses, and even rooftops, while the products are sold to children during school hours.

Chapter 3, "Behind The Counter," gives the reader a glimpse into the lives of those kids who prepare fast food meals. Praised for "obedience," they work with electronic blades and hot oil for long hours at low wages, usually with no benefits or job security. Usually these children come from low-income families. They suffer lifelong consequences from being too tired to do their homework, increasing their likelihood of dropping out of high school, developing substance abuse problems, and committing petty crimes. They are also vulnerable to armed robberies. Schlosser documents that in 1998, more restaurant workers were murdered on the job in the United States than police officers. Most of those violent crimes are committed by disgruntled former employees. The restaurant industry lobby vigorously fights against government regulation of workplace safety guidelines. Attempts by workers to unionize have resulted in restaurants closing, only to reopen down the street.

Chapter 4 is sarcastically entitled "Success." It talks about the odd combination of starting your own business while working for someone else, that is the life of a franchisee. McDonald's Corporation owns nearly all the restaurant buildings and the franchisee must rent from them. She/he is required to follow strict regulations concerning every aspect of the restaurant, such that any business creativity is regarded as disobedience and can result in immediate eviction and the loss of the entire investment. In addition, the franchisee is often required by the fast food company to sign a contract waiving her/his legal right to file complaints. Despite these flaws, the Small Business Administration grants government-backed loans to these 
franchises. When the business fails, the corporation loses nothing, and American taxpayers pay the bill.

Section Two, "Meat and Potatoes," goes into the details of how fast food is produced. The information in chapter 4, "Why the Fries Taste Good," resulted in a huge lawsuit by vegetarians against McDonald's Corporation which, it was discovered, adds natural beef flavor to the potatoes before frying. Today the typical American eats more than 30 pounds of frozen french fries a year. The author details how three giant potato processing companies exert their buying power over a large number of potato farmers in order to drive down the price and force them to increase productivity. Farmers must take out huge loans to buy modern harvesting equipment - or else go out of business. Out of every $\$ 1.50$ spent on an order of fries, only 2 cents goes to the farmer. Family farms are being replaced by huge, corporate-owned farms, where the farmers who have lost their land now work for wages. Schlosser concludes that the "American Dream" is dissolving and being replaced by a new kind of feudal system.

Chapter 6, "On the Range," describes how mass food technology has similarly affected the cattle ranchers. A few large meatpacking firms have monopolized the beef market, artificially depressing prices and driving independent ranchers out of business. Similarly, the nation's chicken growers are controlled by the terms of the chicken processors and impoverished by debt, largely as a result of the mass-produced Chicken McNugget. Schlosser reflects upon the traditional cowboy - the proud, hard-working, independent landowner - who is now a part of history. The suicide rate among America's farmers and ranchers is three times higher than the national average. The author tragically describes how the heart of America has been broken.

Chapters 7 and 8, "Cogs in the Great Machine" and "The Most Dangerous Job," provide an inside view of the meat-packing industry, where migrant workers and the urban poor transform live cows into vacuumsealed packages of hamburgers. In these slaughterhouses, workers are always pushed to work faster. Injured employees are prevented from seeing a doctor and ordered to falsify industry safety records. Schlosser reports that a former slaughterman stated: "They used me to the point where I had no body parts left to give ... then they just tossed me into the trash can." The large meatpacking firms work with the federal government to destroy the labor unions and minimize safety inspections.

They have turned one of the nation's best-paying manufacturing jobs into one of the lowest-paying, created a migrant industrial workforce of poor 
immigrants, tolerated high injury rates, and spawned rural ghettos in the American heartland. Crime, poverty, drug abuse, and homelessness have lately taken root in towns where you'd least expect to find them.

Chapter 9, "What's in the Meat" deals with the dangers of meat contamination. "Every day in the United States, roughly 200,000 people are sickened by a foodborne disease, 900 are hospitalized, and fourteen die." Because of mass production technology, one food poisoning outbreak can spread throughout the entire country, sickening millions of people. E coli is caused by meat coming into contact with fecal material due to unsanitary slaughterhouse practices and overcrowded feedlots, where cows accidentally eat their own waste in addition to being fed chicken manure, and the dead meat and blood of potentially diseased animals.

Fast Food Nation reveals how the meatpacking industry lobby does all it can to block federal safety standards. Under current law, the USDA cannot demand, but can only suggest, a recall of dangerous meat. It cannot force the company to reveal where the meat has already been shipped. Irradiation of meat by nuclear waste is used to kill microorganisms. This does help reduce the reproduction of the disease-carrying bacteria, but it does not provide the meat industry with any incentive to improve the sanitary conditions.

Chapter 10, "Global Realization," talks about the opening of restaurants throughout Europe, Asia, Australia, and the Middle East. Fast food demands the reorganization of the agricultural supply network. The highfat, Americanized diet brings with it obesity, heart disease, diabetes, colon cancer, and breast cancer. As Schlosser so aptly demonstrates, the true cost of fast food is not reflected in the price of a burger.

The Epilogue, dubbed "Have it Your Way," reveals an alternative to fast food. It describes an organic farm in Colorado where cows roam freely and eat primarily grass, rather than cattle feed produced from the rendered remains of other animals. The farm supplies a restaurant called the Red Top, where the burgers and fries are homemade and the employees are treated like family. The business enjoys steadfast customer loyalty while the Wendy's restaurant across the street remains half-empty.

The author predicts that the twenty-first century will be marked by the challenge of balancing efficiency with morality in the market. He gives a number of recommendations on how the government could act to improve the situation, including banning junk food advertising aimed at children; eliminating corporate tax breaks and strictly enforcing food safety, minimum wage and workers' rights legislation; and the creation of a unified fed- 
eral food inspection agency that is independent of the task of promoting sales. He concludes with the comment that nobody in the United States is forced to buy fast food and a plea to the consumer to increase the market for more wholesome food. "The executives who run the fast food industry are not bad men. They are businessmen. They will sell free-range, organic, grass-fed hamburgers if you demand it."

Schlosser's analysis is scholarly, but also extremely personal and emotional in tone. His book is important, especially for Muslims concerned about halal food. Muslims need to have a greater knowledge of the fast food industry, like that presented in Schlosser's book, in order that their halal food is more than just cosmetic (as in halal chicken nuggets). The Qur'anic call for inner purification and protection of Earth's resources necessitates an understanding of the damage being done by multinational corporations. Schlosser's book assists Muslims in the goal of reform.

Maria Hussain

Research Assistant, Whyislam.org

Piscataway, NJ 